\title{
ISLAMIC ORGANIZATIONS IN NORTH SUMATRA The Politics of Initial Establishment and Later Development
}

\author{
Al Rasyidin \\ UIN Sumatera Utara, Medan - Indonesia | ralrasyidin@yahoo.com
}

\begin{abstract}
This paper describes the politics of initial establishment and later development of four Islamic organizations in North Sumatra: Muhammadiyah, Al Jam iatul Washliyah, Nahdlatul Ulama, and Al Ittihadiyah. It particularly focuses on the historical evolution and dynamics of these four Islamic organizations. As a subject of analysis, it, for the most part, assesses the aspects of ethnicity, religious doctrine, educational institution, and political aspiration reflected by these organizations in that area. The paper shows that these four organizations have contributed much to the progress of the Islamic community in this region.
\end{abstract}

Keywords: Muhammadiyah, Al Jam `iatul Washliyah, NU, Al Ittihadiyah, ethnicity, religious doctrine, educational institution.

\section{Introduction}

The early twentieth century is a very important moment in the history of Islamic revival in Indonesia. At the time, spearheaded by a number of well-known ulama, Islamic organizations were founded and then spread to a variety of regions in Indonesia. Social, political, economic, educational, and religious conditions of Muslim communities (ummah) were the driving factors of the emergence of these Islamic organizations. ${ }^{1}$

\footnotetext{
${ }^{1}$ In this context Karel A. Steenbrink states that there were four factors of Islamic revival in Indonesia in the early twentieth century. First, the desire to use the Qur'an and Hadith as the main measure to evaluate existing religious and cultural traditions. Second, the national struggle against the Dutch colonial government. Third, the intense effort by Muslims to strengthen their organizations in socio-economic aspects, be it for general or individual interests. Fourth, the renewal of Islamic education. Karel A.
} 
Socially, the exploitative policies and treatment of the Dutch colonial government against the Indonesian people, especially Muslims, had aroused their solidarity, commonality, and unity against colonialism. Politically, the implementation of etische politeik (ethical politics) by the Dutch paved the way for Muslim elites to consolidate the Muslim masses into a force able to free themselves out of the yoke of colonialism. Economically, the colonial policies which often 'inadvertently' convert the people's land into plantation area and the partiality towards non-Muslim traders caused the already suffering Indonesians to be even poorer and more disempowered. These conditions were exacerbated by the Dutch discriminative attitude towards the many religious communities which existed in Indonesia. Even though formally the colonial government stated their neutrality towards religion ${ }^{2}$, in reality this neutrality was not always adhered to. Schools and Christian missionary zending were subsidized significantly by the Dutch. ${ }^{3}$ Conversely, the Muslims were often prevented by the Dutch from proselytizing Islam, and restrictive regulations were implemented against Islamic education and pilgrimage.

In Indonesia, the first Islamic organization was Sarekat Islam (SI or Islamic Association). It was founded by Haji Samanhudi, a batik trader from Lawean, Solo, in 1912. Its main purpose was to invigorate the economic activities of Javanese Muslim traders through the bond of religion. Because Islam was a binding factor, this organization attracted many Muslim traders, obtaining by 1914444.251 members. ${ }^{4}$ In 1923, SI had spread outside Java to the islands of Sulawesi, Kalimantan and Sumatra, including North Sumatra. This rapid development made the Dutch anxious, and caused them to monitor

Steenbrink, Pesantren, Madrasah, Sekolab: Pendidikan Islam dalam Kurun Mmodern (Jakarta: LP3ES, 1986), p. 26-28.

2 See H. Aqib Suminto, Politik Islam Hindia Belanda (Jakarta: LP3ES, 1985).

3 This phenomenon was also perceived by Islamic organizations in North Sumatra. In 1955, general school was given 7 million rupiah of fund, Islamic school 1 million rupiah, Catholic school 12 million rupiah, and Protestant school 6 million rupiap. See Bahrum Djamil, "Masa Depan Madrasah/Perguruan Al Washliyah," Nukman Sulaiman (ed.), Al Jam'iyatul Washliyah 1/4 Abad (Medan: Pengurus Besar Al Jam'iyatul Washliyah, 1955), pp. 21-25.

${ }^{4}$ See Fred vo der Mehden, Sarekat Islam (Oxford: Oxford University Press, 2011); M.C. Ricklefs, Sejarah Indonesia Modern 1200-2008 (Jakarta: Serambi, 2008), pp. 358-365. 
the activities and actions of SI. Within a short period of time, a number of other Islamic organizations with a national scale along with their prominent, key figures emerged which later played an important part in the struggle for Indonesian independence in 1945. Some examples are Muhammadiyah (founded by Ahmad Dahlan in 1912) ${ }^{5}$, Al-Irsyad and Indonesian Arab Party (Partai Arab Indonesia) (by Ahmad Surkati in 1914), Nahdlatul Ulama (NU, by Hasyim Asy'ari in 1926) 6 , and Ahmadiyah (by Mirza Wali Ahmad Beid in 1929)..$^{7}$ These Islamic organizations had played a great role in the progress of political, economic, social and educational aspects Indonesian Muslims' life.

The emergence of such national-scaled Islamic organizations, in turn, inspired the growth of local or regional Islamic organizations. The return of a number of Indonesian ulama to their hometowns also played an important part in this emergence. ${ }^{8}$ In West Sumatra, led by Middle Eastern universities' alumni, Sumatera Thawalib (1918), which later changed its name into Persatuan Muslim Indonesia (Association of Indonesian Muslim), was founded. In West Java, Hasan Bandung founded Persatuan Islam (1923) (Islamic Unity) as a continuation of Jam'iyatul Khair which was previously seized by the Dutch colonial government. In South Kalimantan, Shaykh Abdurrasyid Amuntai founded Musyawaratut Thalibin as a continuation of Sarekat Islam (SI). In Aceh, Tgk. M. Daud Beureueh founded Persatuan Ulama

\footnotetext{
${ }^{5}$ See Abdul Munir Mulkhan, Kiai Ahmad Dablan: Jejak Pembaruan Sosial dan Kemanusiaan (Jakarta: Kompas, 2010).

${ }^{6}$ See Greg Fealy and Greg Barton, Nabdlatul Ulama Traditional Islam and Modernity in Indonesia (Australia: Monash University, 1996).

7 See Iskandar Zulkarnain, Gerakan Ahmadiyah di Indonesia (Yogyakarta: LKiS, 2005). The existence of Ahmadiyah was censured by North Sumatra ulama and Islamic organizations such as Al-Washliyah, Muhammadiyah, NU and Al-Ittihadiyap. All North Sumatra ulama accused the founder and follower of Ahmadiyah as disbelieved (kafir). See Muslims Scholars Council of North Sumatra (Majelis Ulama Indonesia Sumatera Utara), Fatwa \& Hukum tentang Jema'ah Abmadiyah Qadiyany (Medan: MUI Sumatera Utara, n.d.).

8 See Abdurrahman Mas'ud's analysis, Dari Haramain ke Nusantara: Jejak Intelektual Arsitek Pesantren (Jakarta: Kencana, 2006); Abdurrachman Mas'ud, Intelektual Pesantren: Perbelatan Agama dan Tradisi (Yogyakarta: LKiS, 2004). According to Azra, this phenomenon had existed since the time Islamic Kingdom in XVII and XVIII centuries. See Azyumardi Azra, Jaringan Ulama Timur Tengah dan Kepulauan Nusantara Abad XVII \& XVIII: Akar Pembaruan Islam Indonesia (Jakarta: Kencana, 2005).
} 
Seluruh Aceh (1939) (Aceh Ulama Association) as a continuation of SI. In West Nusa Tenggara, Nahdlatul Wathan was founded as a continuation of SI with the aim to increase the religiosity of Muslims through the establishment of Islamic educational institution. ' These local Islamic organizations contributed to increasing both the quantity and quality of the Muslim communities in their respective organizations.

In North Sumatra, local Islamic organizations were pioneered by ulamas who graduated from the Middle East. Minangkabau settlers founded Muhammadiyah in Medan in 1927. Later, in 1930, seniorstudents of Maktab Islamiyah Tapanuli (MIT) founded AlJami'atul Washliyah (later known as "Al-Washliyah").10 In 1930, Shaykh Musthafa Husain Purbabaru founded Persatuan Muslim Tapanuli (Tapanuli Muslim Association) which later was merged into NU. ${ }^{11}$ In 1935 together with his students, Shaykh Ahmad Dahlan founded Al-Ittihadiyah di Medan. ${ }^{12}$

Similar to Islamic organizations in other regions, these local North Sumatra organizations (Al-Washliyah, Muhammadiyah, NU, and AlIttihadiyah) have contributed much to the progress of North Sumatra Muslim community. During the colonial era, they were quite active in consolidating Muslim unity against the Dutch colonialization. When Indonesia has gained its independence, they continued to exist with a variety of programs and activities for the betterment of the Muslim community in this region. They have had their own distinct historical backgrounds, paths, maps, and strategies for these endeavors.

This paper aims to discover the historical evolution and dynamics of these four organizations. It particularly focuses on summarizing and synthesizing the existence and continuity of North Sumatra Islamic organizations.

\footnotetext{
9 See Deliar Noer, Gerakan Modern Islam di Indonesia 1900-1942 (Jakarta: LP3ES, 1994), pp. 80-103, pp. 114-189; Howard M. Federspiel, Persatuan Islam Islamic Reform in Twentieth Century Indonesia (Singapura: Equinox Publishing Pte. Ltd., 2009), pp. 138-139.

10 See Hasan Asari, Modernisasi Islam: Tokoh, Gagasan dan Gerakan (Bandung: Citapustaka Media, 2002), pp. 230-236.

${ }^{11}$ See Abbas Pulungan, Riwayat Singkat Syekh Musthafa Husein, Syekh Abdul Halim Khatib dan Haji Abdullah Musthafa (Medan: Perdana Publishing, 2012), pp. 26-28.

12 See Anzizhan and Syafaruddin, Visi Baru al-Ittibadiyah (Bandung: Citapustaka Media, 2004).
} 


\section{A Historical Snapshot of Islamic Organizations in North Sumatra}

In North Sumatra, a number of Islamic organizations had grown rapidly even before the time of independence. Among these Islamic organizations were Muhammadiyah, Al Jamiiyatul Washliyah, NU, and Al-Ittihadiyah. These four organizations had managed to benefit the Muslim communities they have served well in social, political, economic, or Islamic educational aspects. They also played a great role in developing Islam in North Sumatra.

\section{Muhammadiyah}

Historically, the founding of Muhammadiyah in North Sumatra cannot be separated from the role of Minangkabau trader settlers in this region. In 1925, some of these traders-Djuin St. Penghulu, St. Saidi Djamaris, Dt. Bungsu and their friends-met Mas Pono, a trader from Yogyakarta who was visiting Medan. It was not known who started the idea of founding Muhammadiyah in Medan, but conversations among them revealed that they had this same idea. They considered many societal religious practices which they thought as having been deviated from the Qur'an and Sunnah, especially innovations and myths, as their reason to believe that Muhammadiyah needed to be founded in this region. Nevertheless, they realized that the actualization of their idea was not easy. In addition to the difference in religious doctrines between them and the majority of Muslims in North Sumatra, it was realized that they were not ulama and had no experience in organizations. They were merely small traders who did business in daily necessities in plantations around Medan. ${ }^{13}$ As such, the only agreement they reached in the initial conversation was to find peers who had the same vision as them. This effort was done through the identification of someone's mannerism in performing the prayers. Almost every day, near the circular market in Medan, where Djuin St Penghulu, Mas Pono, St Maradjo, Kari Suib and their friends agreed to found Muhammadiyah, these traders sought to gather a number of friends who shared their vision. They also lobbied HR. Muhammad Said-a former Vice President of Sarikat Islam Pematang Siantar and a journalist for the Pewarta Deli newspaper - so

\footnotetext{
13 See Abdul Mu'thi, "30 Tahun Muhammadiyah di Daerah Sumatera Timur," in 30 Tahun Mubammadiyah di Daerah Sumatera Timur (Medan: Panitia Besar Peringatan, 1957), p. 99.
} 
that he would be willing to head Muhammadiyah when it was later founded. ${ }^{14}$

Two years later, on 25 November 1927, after a fierce debate at Nagapatan Street 44 -now Kediri Street, Kampung Keling, MedanMuhammadiyah was founded as a branch of Muhammadiyah of Yogyakarta (founded by K.H. Ahmad Dahlan). The visit of AR Sutan Mansur with M. Fakhruddin as the messengers of Hoofdbestuur Muhammadiyah to Medan and Aceh in May 1927 also increased and strengthened the spirit to found Muhammadiyah. ${ }^{15}$ At that time, HR. Muhammad Said was elected as the chairman. However, because the Decree of Hoofdbestuur Muhammadiyah was only issued in 1 Juli 1928, ${ }^{16}$ this year instead of the previous one was stated as the year of Muhammadiyah establishment in North Sumatera.

After its official establishment, proselytization was the tool used by Muhammadiyah to spread and broaden its organization to a variety of regions in North Sumatra. Gatherings and sermons were often conducted. The themes for discussion, even though in several aspects were related with life and moral issues, focused mainly on the legal (fighiyah) issues, such as usalli, qunut, correcting the direction of the qiblah, prayer with necktie, feast after someone's demise, visit to sacred graves, Eid prayers in open fields, and recommended (sunnab) prayer of 11 bows (rakaat) in Ramadan. In East Sumatra, especially in Medan, these issues were hotly debated.

The subsequent effort undertaken by Muhammadiyah to spread its doctrine was to found modern schools modeled after the Dutch schools. These schools turned out to attract societal interest proved by the increase in the number of parents who registered their children there. Year after year, the number of Muhammadiyah schools increased rapidly. This benefited Muhammadiyah as it became easier for the leaders of this organization to spread their doctrine to society.

Only three years after its founding in Medan (1927-1930), there were already 10 branches of Muhammadiyah in East Sumatra. These

14 M. Nur Haitamy, "Muhammadiyah Daerah Sumatera Timur," in 30 Tabun Mubammadiyah di Daerah Sumatera Timur (Medan: Panitia Besar Peringatan, 1957), p. 177.

15 HB. Moehammadijah, Moehammadijah Hindia Timur 1927-1932 (Jogjakarta: HB Moehammadiyah, 1933), p. 4.

16 M. Daud Remantan, "Gerakan Pembaruan Islam di Aceh (1914-1953)" (Unpublished Dissertation, IAIN Syarif Hidayatullah, 1986), p. 98. 
branches can be found in the area of Pancurbatu, Pematang Tanah Jawa, Tebing Tinggi, Kisaran, Pematang Siantar, Kerasaan, Glugur, Tanjung Balai, Binjai and Perdagangan. From Sibolga - which was still part of Tapanuli Residency - Muhammadiyah spread its wings to Padangsidempuan, Sipirok, Tamiang, and surrounding areas. ${ }^{17}$ Until the 1990s, Muhammadiyah had 90 branches which spread across 12 regencies/cities: Medan, Langkat, Deli Serdang, Karo, Dairi, Tebing Tinggi, Asahan-Tanjung Balai, Simalungun-Pematang Siantar, Tapanuli Tengah, Tapanuli Selatan, Labuhan Batu, and Nias.

In addition to proselytization, ${ }^{18}$ to spread its doctrine and to increase its audiences, Muhammadiyah also had the strategy to build places of worship such as masjid (mosque) and musalla (little mosque). Until 2005, Muhammadiyah of North Sumatra had built 257 Masjid Taqwa and 137 musalla. In every masjid and musalla, properly and intensively planned, a number of sermons and religious gatherings were conducted. As such, Muhammadiyah not only developed its membership, but also spread its doctrines to non-Muhammadiyah members.

Muhammadiyah educational institutions also played a large role in developing organizational doctrines. ${ }^{19}$ In 1990, Muhammadiyah had managed 63 units of TK Bustanul Atfal (kindergarten), 109 units of primary schools, 64 units of junior high schools, 36 units of senior high schools, and 3 units of pondok pesantren (Islamic boarding school). In 2005, Muhammadiyah managed to increase the number of its educational institution, including 81 units of kindergarten, 220 units of primary schools, 75 units of junior high schools, 41 units of senior high schools, 3 units of Islamic boarding school, 1 unit of school for

\footnotetext{
17 Tanwir Ahmad Nasution, Sejarab Berdirinya Daerah Mubammadiyah Kabupaten Tapanuli Selatan (n.p: n.d., 2005), p. 1.

18 Muhammadiyah also fought against the Christian propagation movement in Indonesia, including in North Sumatra, even though Al-Washliyah was more successful than Muhammadiyah. An analysis of Muhammadiyah's role in containing this Christian propagation movement role, see Alwi Shihab, Membendung Arus: Respons Gerakan Muhammadiyah terhadap Penetrasi Misi Kristen di Indonesia (Bandung: Mizan, 1998).

19 The foundational concept of Muhammadiyah has been analyzed in an interestingly by Dja'far Siddik, “Konsep Pendidikan Islam Muhammadiyah: Sistematisasi dan Interpretasi Berdasarkan Perspektif Ilmu Pendidikan" (Unpublished Dissertation: IAIN Sunan Kalijaga, 1997); Dja'far Siddik, Pendidikan Mubammadiyah Perspektif Ilmu Pendidikan (Bandung: Citapustaka Media, 2007).
} 
people with disability, and 5 units of universities. ${ }^{20}$ These Muhammadiyah educational institutions are spread over the 19 regencies/cities in North Sumatra, and became an important channel of communication to distribute Muhammadiyah's religious doctrines.

\section{Al-Jam'iyatul Washliyah}

The emergence of Muhammadiyah with its "new religious doctrine" brought out a 'harsh' reaction among the native Muslim communities and Mandailing ethnic group in East Sumatra. On the one hand, this reaction was caused by Muhammadiyah's statements which pointed out that many of the 'old group' (kaum tua) traditions were not Islamic. In a number of tablighs (religious learning forums), Muhammadiyah figures always spread their 'modernist' doctrine which was in opposition with the kaum tua. On the other hand, this reaction resulted from the fact that the influence of Minangkabau ethnic group had become stronger in society due to their success in developing modern Muhammadiyah schools which attracted many Muslim parents who wished their children to study there. For many Mandailings, the Minangkabaus were viewed as 'invading' their territory. This was despite the fact that the Mandailing settlers had enjoyed social, economic, and religious prestige because of the educational opportunities provided for by the Minangkabaus.

The Mandailing ethnic group itself was divided into two camps with regards to this so-called Minangkabau's 'invasions'. The first camp consisted of senior Mandailing elites who sought the protection of the Malay sultans. They realized that the Sultanate felt a deep antipathy against Muhammadiyah. The second camp included young Mandailing generation consisting of senior students of Maktab Islamiah Tapanuli or MIT $^{21}$ who formed a debating club to discuss and counter Muhammadiyah's modernist doctrines.

20 Abbas Pulungan et. al., Sejarah dan Dinamika Organisasi Islam di Sumatera Utara (Medan: Institut Agama Islam Negeri Sumatera Utara, 2005), pp. 165-166.

21 Maktab Islamiyah Tapanuliis the oldest madrasah (Islamic school) in Medan, East Sumatra, which now has become the capital city of North Sumatra. It was founded by Mandailing settlers in Medan, and was inaugurated on 19 May 1918. The first nazir was Shaykh Muhammad Yakub, P. Ibrahim Penghulu Pekan and Sei Kerah Medan. Syaikh Muhammad Yunus (Al-Washliyah advisor) was the headmaster of this madrasah and a teacher of Al-Washliyah founders. See Muaz Tanjung, "Pendidikan Islam di Medan Pada Awal Abad ke-20: Studi Historis tentang Maktab Islamiyah Tapanuli (19181942)" (Unpublished MA Thesis: PPS IAIN-SU, 2004); Muaz Tanjung, Maktab 
What was initially only a debating club transformed into an organization named Al-Jam'iyatul Washliyah. ${ }^{22}$ Al-Washliyah was founded on 9 Rajab 1349/30 November 1930 in the MIT building in Medan $^{23}$ by senior MIT students such as Ismail Banda, Adnan Nur, Muhammad Arsyad Thalib Lubis, Abdurrahman Syihab and Muhammad Yusuf Ahmad Lubis, all of whom were students of Shaykh Muhammad Yunus and Shaykh Hasan Maksum, ${ }^{24}$ two prominent ulamas in East Sumatra. These Al-Washliyah founders were of Mandailing ethnicity.

The Al-Washliyah founders determined to spread Islam in North Sumatra, and even in Indonesia. The initial purpose of Al-Washliyah founding was to "advance, accentuate, and increase the spread of Islam." In 1934 the same aim was formulated in the following words "to fulfill the demands of Islam". ${ }^{25}$ According to the statute of AlWashliyah in 1977, Al-Washliyah was founded "to fulfill the demands of Islam in its entirety." Then, it was also firmly stated that in the field of theology, Al-Washliyah adopted the Ahl al-Sunnah Wa al-Jamàah theological doctrine, and in law (figh) adopted (or prioritized) the Shafi'i school of thought. ${ }^{26}$ It could be said that Al-Washliyah was the

Islamiyah Tapanuli 1918-1942: Menelusuri Sejarah Pendidikan Islam Awal Abad ke-20 di Medan (Medan: IAIN Press, 2012), pp. 60-61, pp. 117-124.

22 The name "Al Jam'iyatul Washliyah" was given by Shaykh Muhammad Yunus, a North Sumatra ulama and the Headmaster of Maktab Islamiyab Tapanuli. See Pangadilan Daulay and Hawari Arsyad Lubis (ed.), Al Jam'iyatul Washliyah Memasuki Millenium III: Kado Ulang Tahun Al-Washliyah ke-69 tabun 1999 (Jakarta: Pengurus Besar Al-Washliyah, 1999), p. 16.

${ }^{23}$ Chalidijah Hasan, Al Jam'iyatul Washliyah: Api dalam Sekam (Bandung: Pustaka, 1988), p. 11.

${ }^{24}$ See the life history of these Al-Washliyah founders in Majelis Ulama Indonesia Sumatera Utara (North Sumatra Council of Indonesian Ulama), Sejarah Ulama-ulama Terkemuka di Sumatera Utara (Medan: IAIN Sumatera Utara, 1983); Ja'far, Biografi Intelektual Ulama-ulama Al-Washliyah (Medan: Centre for Al-Washliyah Studies, 2012).

25 Udin Syamsuddin, Chutbah Pengurus Besar Memperingati Ulang Tabun al-Djam'iyatul Washlijab Seperempat Abad (30 November 1930-30 November 1955) (Medan: PB alJam'iyatul Washliyah, 1955), p. 3-4.

${ }^{26}$ See the Board of Al Jam'iyatul Washliyah, Al Jam'iyatul Washliyah (Medan: Pengurus Besar Al Jam'iyatul Washliyah, 1977), p. 1; Board of Al Jam'iyatul Washliyah, Anggaran Dasar dan Anggaran Rumah Tangga Al Jam'iyatul Washliyah Periode 2003-2008 (Jakarta: PB Al-Washliyah, 2003); Board of Al Jam'iyatul Washliyah, Anggaran Dasar dan Anggaran 
fort of the Sunni Muslims in North Sumatra through the development of Shäfíiyah dan Ash'ariyah schools of thought ${ }^{27}$ in Islamic schools (madrasah) and universities, as well as through its ulamas' writings. Siradjuddin Abbas even considered Al-Washliyah as an Islamic association which provided a great service to uphold and spread the Shäi $\bar{T}^{\overline{1}}$ yah school of thought in East Sumatra. ${ }^{28}$

At the beginning, Al-Washliyah was not well received in Medan by some Muslim figures from different ethnic groups, including Mandailing senior elites. Among the reasons were that Al-Washliyah youth leaders had not obtained legitimacy in the eyes of the elites, and the Malay ethnic group was not included in Al-Washliyah executive committee. As such, two years later the Al-Washliyah committee recruited senior Mandailing and Malay elites, including prominent ulamas and Malay noble people. The prevailing Mandailing leaders even appointed Tengku H.M. Anwar-a relative of the Asahan Sultanates- as the Executive Chairperson and Shaykh Hasan Maksum, ${ }^{29}$ the ulama of the Deli Sultanate, as an advisor and the Chairperson of Al-Washliyah Fatwa Board. ${ }^{30}$ These strategies were successful in attracting the Muslim community's sympathy to join AlWashliyah.

After the reorganization, Al-Washliyah was requested to open branches and set up Islamic schools in a number of regions. It became popular in these different regions, from Asahanto Sibolangit. The

Rumah Tangga Al Jam'iyatul Washliyah Periode 2010-2015 (Jakarta: Pengurus Besar Al Jam'iyatul Washliyah, 2010).

27 See Ramli Abdul Wahid's study, “Al-Jam'iyatul Washliyah: Studi tentang Madzhab Akidah dan Fikih," in Saiful Akhyar Lubis (ed.), Peran Moderasi Al-Washliyab: Merajut Kebersamaan Zaman Berzaman (Medan: UNIVA Press, 2009).

28 Siradjuddin Abbas, Sejarah dan Keagungan Madrhab Syafi i (Jakarta: Pustaka Tarbiyah Baru, 2006), p. 374. Abbas also mentioned the role of Shaykh Hasan Maksum (Head of Al-Washliyah's Fatwa Committee) and Shaykh Abdurrahman Syihab (founder and former Chairperson of Al-Washliyah) in strengthening the hold of Shafi'i school of thought in East Sumatra.

${ }^{29}$ Shaykh Hasan Maksum is a student of Shaykh Ahmad Khatib al-Minangkabawi as was Shaykh Musthafa Husain of NU and KP. Ahmad Dahlan of Muhammadiyap. As such, these 3 ulamas with their various orientation spent time learning from the same teachers.

${ }^{30}$ Tengku Luckman Sinar, Sejarah Medan Tempo Doeloe (Medan: Perwira, 2007), pp. 8690. 
opening of branches in these regions was always accompanied by the setting up of a number of schools, including Islamic kind. In 1955, AlWashliyah set up Islamic educational institutions at a variety of levels. These levels ranged from the Tajbizi (2 years), Ibtidai (6 years), Tsanawiyah (3 years) and al-Qismul 'Aly (3 years). These institutions were popular and attracted students from a variety of social strata. In 1941, Al-Washliyah had 242 schools with 12,500 students. This number continued to increase, especially after Al-Washliyah implemented the policy of transforming privately owned madrasabs into Al-Washliyah madrasahs, and modernized its education system by adopting Muhammadiyah school system. However, different from Muhammadiyah which emphasized school developments deemed secular, Al-Washliyah undertook the policy of developing Islamic kind of school in primary, secondary and tertiary levels. ${ }^{31}$

Currently, Al-Washliyah in North Sumatra has had 148 general schools and 461 religious schools, making a total of 609 units of educational institutions from primary to secondary levels. ${ }^{32}$ At the tertiary level, Al-Washliyah in North Sumatra has had 5 units of institutions, including University of Al-Washliyah (UNIVA) in Medan and Labuhanbatu, Universitas Muslim Nusantara (UMN) AlWashliyah, Sekolah Tinggi Ilmu Ekonomi (STIE) Al-Washliyah in Sibolga, and Sekolah Tinggi Ilmu Tarbiyah (STIT) in Binjai. ${ }^{33}$ Based on these data, it is clear that Al-Washliyah has contributed positively to educate the Muslim community of North Sumatra.

In addition, Al-Washliyah has been very active to contain the Christian proselytization movement in North Sumatra. At the al-Islam Congress in Solo on 7-8 July 1941, it was decided that Al-Washliyah formed a committee headed by Abdurrahman Syihab specifically for

\footnotetext{
${ }^{31}$ See Sulaiman (ed.), Al Jam'iyatul W ashliyah.

32 Regional Leadership (Pimpinan Wilayab) of Al Jam'iyatul Washliyah, Laporan Umum Pimpinan WIlayah Al Jam'iyatul Washliyah Sumatera Utara: Musyawarah Wilayah X Al Jam'iyatul Washliyah Sumatera Utara (Medan: PW Al-Washliyah Sumatera Utara, 2003), p. 8-10.

${ }^{33}$ See Hasbi Jasin (ed.), Al Jam'iyatul Washliyab: Sekilas Catatan Muktamar Penuh Kasih Sayang Menghasilkan Demokrasi Yang Utuh (Jakarta: PB Al Jam’iyatul Washliyah, 1997), pp. 38-40. Compare with Dja'far Siddik, et al, Lembaga-lembaga Pendidikan Al-Washliyab: Tipologi, Eksistensi dan Problematika (Medan: Lemlit IAIN Sumatera Utara, 2012). For an elaboration of Al-Washliyah University (UNIVA) history, see Muhammad Hasballah Taib, Universitas al-Washliyah Medan: Lembaga Pengkaderan Ulama di Sumatera Utara (Medan: UNIVA, 1993).
} 
the proselytization of Islam in North Sumatra. Some activities were oriented to do proselytizing for the Christian Bataks. ${ }^{34}$ Al-Washliyah ulamas, including Shaykh Muhammad Arsyad Thalib Lubis, wrote very actively Islamic ideas in Bataknese. ${ }^{35}$

\section{Al-Ittihadiyah}

Like Al-Washliyah, Al-ittihadiyah is also an indigenious Islamic organization in North Sumatra. It was founded on 21 Shawwāl 1352 or 27 January 1935 by KH. Ahmad Dahlan -an ulama of Tanjungpura, Langkat, who once studied in the Middle East. Al-Ittihadiyah founding was officiated in Zelfstanding Yong Islamiten Bond Building, Medan. ${ }^{36}$ Its founding was a response to the political and socio-religious development in North Sumatra. At that time, the Dutch launched a political strategy of divide-and-conquer to weaken the strength of the Muslim community and destroy the ulama to reinforce its power in Indonesia definitely. This political strategy fooled some Muslims in such a way that Muslim 'factions' arose against each other. On the one hand, 'Westernized' elites emerged, who belittled the ulama and the Muslim community, accusing them as 'orthodox'. On the other hand, some ulama and parts of the Muslim community accused the intellectuals as 'foot soldiers' of the Dutch. The dispute against these two groups became worse over time. ${ }^{37}$ In this context, Al-Ittihadiyah emerged to bridge and unify local Muslim communities. ${ }^{38}$

When it was officiated, Al-Ittihadiyah firmly stated that it was a follower of the Sunni (Ahl al-Sunnah wa al-Jamāah) creed, which is compatible with the creed of Abū al-Ḥasan al-Ash'arì and Abū Manșūr

\footnotetext{
${ }^{34}$ Deliar Noer, Gerakan Modern Islam di Indonesia, p. 266.

35 Some of Muhammad Arsyad Thalib Lubis works are Peladjaren Sembabjang; Bena-bena Kepertjajaen Ibagessen Agama Islam; Parsiadjaran Sombajang; dan Dasaring Kapertjajan Ing Agama Islam.

36 Djanius Djamin, "Selayang Pandang Kiprah Al-Ittihadiyah," in Anzizhan and Syafaruddin (ed.), Al-Ittihadiyah: Menjalin Kebersamaan Membangun Bangsa (Jakarta: Hijri Pustaka Utama, 2006), pp. 36-37.

${ }^{37}$ Bachroem Azhar, et al., Buku Peringatan Ulang Tabun 1/4 Abad Al-Ittihadiyah (Medan: Pengurus Besar Al-Ittihadiyah, 1960), p. 15.

38 C.V.O Conferentie Al-Ittihadiyah, "Azas, Toejoean, Oesaha, dan Organisatie AlIttihadiyah," in Conferentie Jubilieum 6 Tahoen 1935-1941 Al-Ittihadiah (n.c.: C.V.O. Conferentie Al-Ittihadiah ke-I, 1941), p. 16.
} 
al-Māturìdi. ${ }^{39}$ While in fiqh, in the beginning, Al-Ittihadiyah formally stated its 'neutrality' against the four madhhab (school of Islamic thought), Shāfi'ìi, Māliki, Hanbali, and Hanafi. However, over time, this neutrality faded, and Al-Ittihadiyah stated its preference of the Shafi $\bar{i}$ madhbab. ${ }^{40}$

Not much different from Muhammadiyah and Al-Washliyah, education, proselytization, and social charity are the primary endeavors of Al-Ittihadiyah. In education, Al-Ittihadiyah introduced a dual-system of madrasah and modern schools, which became a 'bridge' for AlIttihadiyah to develop its organization. Al-Ittihadiyah managed to 'package' this organizational growth along with madrasah and school development. In addition, madrasah teachers and Al-Ittihadiyah schools also become the 'mouthpiece' of Al-Ittihadiyah in its regional expansion. During its initial founding, Al-Ittihadiyah has spread Islam to those who have not adopted a particular religion. Also, it established orphanages which, in turn, gained the sympathy of society to join it.

As it was supported by the sultans, nobles, dan Malay ulamas, AlIttihadiyah's effort to expand in East Sumatra did not encounter any significant obstacles. The similarity of theological creed and legal school of Islamic thought with Al-Washliyah also made it easy for the society to follow Al-Ittihadiyah. As such, Al-Ittihadiyah managed to practically influence almost every region in East Sumatra residency territory.

\section{Nahdlatul Ulama}

Not much different with Al-Washliyah, the emergence of Nahdlatul Ulama (NU) in North Sumatra in 1947 was a response to the religious doctrines developed by the 'youth group'. The founder of NU in North Sumatra is Shaykh Musthafa Husein, an educator and charismatic ulama from the Pesantren Purbabaru, Mandailing. He studied in Mecca under the supervision of Shaykh Ahmad Khatib alMinangkabawi (the Mufti of Shäfi'i madhhab in Mecca) and Shaykh Abdul Kadir al-Mandili (a Meccan ulama from South Tapanuli). In

\footnotetext{
39 See Deliar Noer, Partai Islam di Pentas Nasional (Jakarta: Temprin, 1987), p. 49.

${ }^{40}$ M. Abu Bakar, "Al-Ittihadiyah 1/4 Abad," in Bachroem Azhar, et al., Peringatan Ulang Tabun 1/4 Abad Al-Ittihadiyah (Medan: Panitia Bear Kongres ke X Al-Ittihadiyah, 1960), p. 16.
} 
South Tapanuli, this ulama founded the Pesantren Musthafawiyah ${ }^{41}$ which later became an important vehicle for the spread of $\mathrm{NU}$ in North Sumatra.

The establishment of NU in North Sumatra is a follow-up to Tapanuli Muslim Congress. The Mandailing ethnic group decided to found it because they did not feel sufficiently represented in AlWashliyah and Al-Ittihadiyah. Even though all these organizations had similar theological creed and schools of Islamic thought, Al-Ittihadiyah was dominated by Malays, while Al-Washliyah was represented by only a few member of the Mandailing ethnic group. In the beginning, NU North Sumatra headquarter was located in Padangsidempuan and then moved to Medan in 1953.

The consistency of NU to maintain and monitor the Sunni creed and school of Islamic thought was immediately apparent after its founding. At the time, NU proposed a resolution and motion-of-no confidence to the Tapanuli Officer-in-charge of Islamic Affairs who did not adhere to the Ahl al-Sunnah wa al-Jamāah doctrine. This resolution was conveyed to the Tapanuli Residents in Sibolga and a copy was conveyed to the Governor of North Sumatra and Minister for Religious Affairs in Yogyakarta.

Different from Muhammadiyah, Al-Washliyah and Al-Ittihadiyah, the strategy used by NU to spread its doctrine and develop its organization was through the empowerment of ulama and alumni of Pesantren Musthafawiyah. At the beginning, NU was concentrated in and around South Tapanuli-where the Pesantren Musthafawiyah's alumni lived - which is divided into five regions, Mandailing, Natal and Batang Natal, Padang Lawas, Angkola-Sipirok, and Batang Toru. Later, NU expanded its wings to wider areas in North Sumatra, such as to Langkat, Deli Serdang, and Medan. This expansion was accompanied by the spread of Pesantren Musthafawiyah's alumni to a variety of regions and the significant number of NU cadres who held important posts in a number of government organizations.

The position of ulamas as charismatic, respected and honored figures plays an important role in the development of NU. This could be seen from the history of NU leadership in North Sumatra, where ulamas always held the most important position, be it in the Syuriah or

\footnotetext{
41 Abbas Pulungan, Sejarah dan Keagungan Madžhab Syafi'i, pp. 257-258; see also Abbas Pulungan, Riwayat Singkat Syekh Musthafa Husein, pp. 17-19; MUI Sumatera Utara, Sejarah Ulama-ulama Terkemuka, pp. 165-174.
} 
Tanfidziah. This policy of respect often becomes a 'bridge' for NU to interact with the wider societies and political leaders. It also plays a vital role in attracting Muslims' sympathy to join NU. Through a number of sermons and religious study gatherings, the ulamas successfully influenced their adherents to found chapters and branches of $\mathrm{NU}$ at the level of sub-district and village.

In 1953, NU management structure started to be more flexible as more Malays join the organization. Shaykh Abdullah Afifuddin, a prominent Malay ulama from Langkat, was appointed as Naib Rais I NU (First Vice Leader of NU). Shaykh Afifuddin studied religion in Mecca and at University of al-Azhar in Cairo, Egypt. ${ }^{42}$ Tengku Yafizham, who is also a relative of Sultan Serdang, was appointed as the treasurer. After Shaykh Mustafa Husein died, Shaykh Abdullah Afifuddin was entrusted with the position of Syuriah of NU in North Sumatra (1969-1971), while Tengku Yafizham was given a position in the Tanfidriyah. The cooperation between the Mandailing ethnic group and the Malays were close because both groups adopted the Ahl alSunnah wa al-Jamāà creed and Shāfīi madhhab.

\section{Mapping of Ethnicity, Religious Doctrine, Educational Insti- tution, and Political Aspiration}

Islamic organizations in North Sumatra have their own captive membership. Viewed from the aspect of ethnicity, Minangkabaus are usually Muhammadiyah members, a majority of Tapanuli Batak Muslims and some Mandailings are Al-Washliyah members, a majority of Malays and some Karos are members of Al-Ittihadiyah, and a majority of Mandailings are NU members. Until now, this ethnic affiliation does not seem to have changed very much.

In East Sumatra and Tapanuli residency (now North Sumatra), there are six native ethnicities, Malays, Mandailing Batak, Toba Batak (North Tapanuli), Simalungun Batak, Karo Batak and Dairi Batak. Medan-the capital of East Sumatra-is the native region of the Malays and the important economic centre in East Sumatra. As such, this city attracted many Minangkabau, Mandailing, and the Toba Bataks settlers to trade and make a living. In this city, these ethnic groups interacted and competed for prestige and influence.

\footnotetext{
42 Akmaluddin Syahputra (ed.), Sejarah Ulama Langkat dan Tokoh Pendidik (Bandung: Citapustaka Media, 2012), pp. 66-67.
} 
The inter-ethnic 'competition' begun when the Mandailing ethnic group feared that their influence would be replaced by the Minangkabau ethnic group. One reason is that the tabligh materials conveyed by the Minangkabaus through Muhammadiyah often contradicted the belief and doctrine of the Mandailings. This fear gained momentum when Muhammadiyah schools attracted the interest of more and more members of society. Muhammadiyah schools were not only meant for the Minangkabaus, but for the Malays, the Mandailings, and all other ethnic groups living in East Sumatra. ${ }^{43}$ The 'feud' between these two ethnic groups sharpened and both often ridiculed each other to the point of accusing the other as being 'unbelievers' (käair).

Viewed from their origin area, the Minangkabau and Mandailing ethnic groups actually come from neighboring regions, albeit with different cultures. Minangkabaus are well known as modernist Muslims with a strong matrilineal tradition, especially in terms of succession, inheritance, and legitimation. A similarity of both ethnic groups is the tradition of 'merantau' (emigration to seek a better future). However, for the Minangkabau ethnic group members, emigration is a cultural norm to find and gain economic strength to build their hometowns in the Minang lands. However, for the Mandailing ethnic group members, emigration is a necessity to expand their territory. ${ }^{44}$ As such, when the Minangkabau ethnic group's influence was increased, the Mandailing ethnic group perceived this increase as a 'threat'.

Even though other reasons exist, ethnicity is the main reason which spurred the Malays to found Al-Ittihadiyah. The Malays are not only the native residents of Medan, but also the rulers of East Sumatra. The difference of religious doctrines from the Minangkabaus caused the Malays to be reluctant to join Muhammadiyah. In the meantime, even though they have had similar religious doctrines with AlWashliyah members, the Malays realized that they are not majority members. As such, to establish ethnic existence, the Malays deemed it necessary to found Al-Ittihadiyah.

In addition to ethnicity, affiliation to Islamic organizations in North Sumatra is often spurred by religious doctrines. The

\footnotetext{
43 Abbas Pulungan, et al., Sejarah dan Dinamika, pp. 304-323.

${ }^{44}$ Usman Pelly, Urbanisasi dan Adaptasi: Peranan Misi Budaya Minangkabau dan Mandailing (Jakarta: LP3ES, 1994), p. 185.
} 
Minangkabau ethnic group as the main proponent of Muhammadiyah is a community of modernist Muslims without adherence to any specific madhhabs, and is often called 'kaum muda' (youth faction). AlWashliyah and NU which adhere to the Ahl al-Sunnah wa al-Jamà ah creed and Shäfi'i madhhab are often called 'kaum tua' (old faction). AlIttihadiyah, even though adheres to the Ahl al-Sunnah wa al-Jamà ah creed, has stated its neutrality regarding mazhab. ${ }^{45}$

In North Sumatra, educational institution can provide a description of Islamic organization's history and dynamics. In this region, almost similar to West Sumatra and other regions in Java, modernization of Islamic education was introduced and developed by the 'youth faction' or the modernist Muhammadiyah Muslims. Muhammadiyah schools are modern schools and its beginning were very similar to the Dutch schools. In Muhammadiyah schools, in addition to religious knowledge, general knowledge is also taught, along with the provision of extracurricular activities.

Pesantren is an institution which has always been affiliated to NU. Historically, it can be seen that pesantren in North Sumatra -especially Musthafawiyah Purbabaru-is a base and driving factor for the spread of NU in this region. The pesantren's ulama, teachers, and alumni are 'mouthpieces' which consistently campaign for and spread the NU ideology to society. The nabdliyyin's consistency in preserving their cultural treasures and inheritance can be seen by their success in preserving tradition and the pesantren education system. ${ }^{46}$

In its beginning, Al-Washliyah established traditional madrasah education. However, due to external factors - such as the presence and popularity of Muhammadiyah schools -and the result of comparative study to West Sumatra, Al-Washliyah reformed its madrasab education system by establishing modern madrasah and Islamic schools. The establishment of educational systems is an inseparable part of AlWashliyah's history and dynamics. Wherever Al-Washliyah establishes a branch, there is usually an educational institution in the form of madrasah or Islamic school.

\footnotetext{
45 C.V.O. Conferentie Al-Ittihadiyah, "Azas, Toejoean, Oesaha, dan Organisatie AlIttihadiyah," p. 16.

46 See Abbas Pulungan, Perkembangan Islam di Mandailing (Bandung: Citapustaka Media, 2008), pp. 145-146.
} 
Learning from Al-Washliyah experience, since its founding, AlIttihadiyah has established and developed modern Islamic educational system. Formally, Al-Ittihadiyah stated that its aim in doing this is to attempt to establish Islamic educational institutions and to unite educational institutions not yet affiliated to a particular organization. ${ }^{47}$ As such, Al-Ittihadiyah set up Tabdjizy, Ibtidai, Tsanawi, and Qismu' Aly, madrasabs as well as PGA (Pendidikan Guru Agama, Religious Teacher Training), SR/SD (Sekolah Rakyat/Sekolah Dasar, People's School/Primary School), SMP (Sekolah Menengah Pertama, Junior High School), SMA (Sekolah Menengah Atas, Senior High School) and universities. Up to the New Order era, Al-Ittihadiyah had 275 educational institutions, which comprised of 213 units of Tabdjisy, Ibtidai, Tsanawi, Qismu 'Aly madrasabs and primary schools, 7 units of PGA, 35 units of SMP, 1 unit of SMA, and a university. ${ }^{48}$ Ironically, internal conflict caused many Al-Ittihadiyah's educational institutions to be disbanded, and some changed the status of institutions to become individually owned, a similar occurrence that happened to AlWashliyah's educational institution.

Viewed from a political context, Islamic organizations in North Sumatra have attempted to develop and unite Muslims against Dutch colonialism. Then, affiliation to different Islamic organizations did not become an obstacle to limit cooperation against colonialism. Even during Indonesian independence, organizational affiliation did not cause a split in the Muslim community's political affiliation. Muhammadiyah, Al-Washliyah, Al-Ittihadiyah, and NU, all channeled their political aspiration and become special members of the Masyumi Party, even though NU later resigned and formed its own political party.

When the Old Order government disbanded Masyumi, except for $\mathrm{NU}$, all the other three Islamic organizations still channeled their political aspiration to Parmusi. When the New Order government was formed and the request to reinstate Masyumi was rejected by Soeharto, the three organizations channeled their political aspiration to United

\footnotetext{
${ }^{47}$ Ibid., p. 16.

48 Abbas Pulungan, et al., Sejarah dan Dinamika, p. 302; Al Rasyidin, "Dinamika Historis Al-Ittihadiyah: Refleksi Ormas Islam di Tanah Kelahiran," in Anzizhan and Syafaruddin (ed.), Al-Ittihadiyah: Menjalin Kebersamaan Membangun Bangsa (Jakarta: Hijri Pustaka Utama, 2006), p. 218.
} 
Development Party (Partai Persatuan Pembangunan, PPP).49 NU formed its own political party named after it, even though after the New Order government merged all political parties into three major parties, NU channeled its political aspiration to PPP. 50

When NU was still a political party, it gained a significant number of votes in a number of elections in South Tapanuli. In the 1955 election, Shaykh Musthafa Husain as the founder of NU in North Sumatra issued a written fatwa instructing his students and the Muslims to choose NU. Due to this fatwā, NU obtained the second highest number of votes $(27,34 \%)$ after the Masyumi Party $(37,13 \%)$. In the 1971 election, NU obtained 18\% of votes after Golkar with $68 \%$ votes. In the 1977 election, when all Islamic political parties were merged into one in PPP, NU votes caused PPP to obtain $47 \%$ of votes, second highest after Golkar with $48,60 \%$ votes, while the Indonesian Democratic Party (Partai Demokrasi Indonesia, PDI) only obtained 3,70\% of votes. ${ }^{51}$ Based on these data, as a political party it can be seen that NU always managed to get second place in a number of elections. Even when merged into PPP, NU contributed significantly to the number of PPP votes.

When the Old Order collapsed, empirical surveys showed that the political orientation of Islamic organizations in North Sumatra was divided to several parties. If most Muhammadiyah members channeled their political aspiration to National Mandate Party (Partai Amanat Nasional, PAN) and a few to Nation Sun Party (Partai Matahari Bangsa, PMB), Al-Washliyah and Al-Ittihadiyah channeled their political aspiration to PPP, while NU to Nation Awakening Party (Partai Kebangkitan Bangsa, PKB). At any rate, the split of Islamic political aspiration to a number of political parties has weakened the bargaining position of Muslims in North Sumatra.

In the time of reformasi, an interesting organizational dynamic could be seen in Al-Washliyah and Al-Ittihadiyah. In the last two elections, the Chairperson of Al-Washliyah attempted to direct its members to two different political parties, PKB and the Democratic Party (Partai

\footnotetext{
49 See Haidar Nashir, Dinamika Politik Mubammadiyah (Yogyakarta: Bigraf Publishing, 2000), p. 12.

50 See S. Sinansari Ecip, NU, Khittah dan Godaan Politike (Bandung: Mizan, 1994); Slamet Effendy Yusuf, Dinamika Kaum Santri: Menelusuri Jejak dan Pergolakan Internal NU (Jakarta: Rajawali, 1983).

${ }^{51}$ Abbas Pulungan, Perkembangan Islam di Mandailing, pp. 144-151.
} 
Demokrat, PD). Along with affiliation to these two parties, several AlWashliyah cadres have also become members of other parties such as the Hanura and Golkar party. However, some committee members and most Al-Washliyah members still 'insist' on channeling their political aspiration to PPP. ${ }^{52}$ In this era, not a few Al-Washliyah cadres has managed to become legislative candidates from the regency/city level (DPRD of City/Regency), province level (DPRD of the Province) and national level (DPR RI). Up to the era of the reformasi government, the main positions of Pimpinan Wilayah (Regional Leaders) Al-Washliyah in North Sumatra were held by a number of political party members particularly the Democratic Party, PPP, and the Golkar Party. Of course this phenomenon was different with Muhammadiyah which organization was not dominated by political parties. The split of Al-Washliyah members' political affiliation caused many conflicts of interest between these parties.

A similar case also happened to Al-Ittihadiyah. Even though the main leaders channeled their aspirations to PPP at the regional level, Al-Ittihadiyah members also channeled their political aspirations to other Islamic parties such as PBB and PKS. This split caused an internal conflict because of the tug-and-pull of vested interest between internal and external organizational forces.

In general, the dynamics of Islamic organizations in North Sumatra appears in a series of local election (Pemiliban Kepala DaerahPilkada), be it at the province or regency/city level. In a number of cases, the organizational internal leaders often differ in their political choice. This difference caused an internal conflict which made the Chairperson resign from his position. To a certain extent, except for $\mathrm{NU}$ and Muhammadiyah, Islamic organizational affiliation can no longer guarantee the unity of aspiration and political choice of its members. Viewed from a historical context, this phenomenon can be seen as a significant 'shift'.

\section{Conclusion}

A study of the history and dynamics of Islamic organization in North Sumatra cannot be separated from how Muslims in this region channel their political aspiration and outlook. At the beginning, the difference in organizational affiliation did not cause a difference in

\footnotetext{
52 See Ahmad Hamim Azizy, Al Jam'iyatul Washliyah dalam Kancah Politik Indonesia (Banda Aceh: PeNA, 2006).
} 
political choice. This condition has changed, because only Muhammadiyah and NU can now manage to mobilize its members to channel their political aspiration according to organizational's direction and choice. Al-Washliyah and Al-Ittihadiyah, on the other hand, can be said to have been 'left' by its members. Twice in the reformasi era's elections, Al-Washliyah and Al-Ittihadiyah 'failed' to mobilize its members to follow the organizations' political choice.

In North Sumatra, Muhammadiyah can be said to be a phenomenon of the market. The main proponent of this organization is the Minangkabau traders who live in the 'city' and use the market as a means to develop Muhammadiyah. On the other hand, Al-Washliyah and Al-Ittihadiyah can be said to be a phenomenon of elite and people power at the same time. At the beginning of their founding and through their development, both Islamic organizations were close to power and managed to use it as an effective means of organizational development. However, when the Malay sultans' power declined due to the Social Revolution of 1946, Al-Washliyah and Al-Ittihadiyah changed to become a phenomenon of the 'masses'. Last but not least, $\mathrm{NU}$ can be said to be the phenomenon of ulama, a label which fits its name, Nabdlatul Ulama. []

\section{References}

\section{Books and Articles}

Abbas, Siradjuddin. Sejarah dan Keagungan Madz̧ab Syafi i. Jakarta: Pustaka Tarbiyah Baru, 2006.

Anzizhan \& Syafaruddin (ed.). Al-Ittihadiyab: Menjalin Kebersamaan Membangun Bangsa. Jakarta: Hijri Pustaka Utama, 2006.

--------. Visi Baru al-Ittihadiyah. Bandung: Citapustaka Media, 2004.

Suminto, H. Aqib. Politik Islam Hindia Belanda. Jakarta: LP3ES, 1985.

Asari, Hasan. Modernisasi Islam: Tokoh, Gagasan dan Gerakan. Bandung: Citapustaka Media, 2002.

Azhar, Bachroem, et al.. Buku Peringatan Ulang Tabun 1/4 Abad AlIttihadiyah. Medan: Pengurus Besar Al-Ittihadiyah, 1960.

Azizy, Ahmad Hamim. Al Jam'iyatul Washliyah dalam Kancab Politike Indonesia. Banda Aceh: PeNA, 2006. 
Azra, Azyumardi. Jaringan Ulama Timur Tengah dan Kepulauan Nusantara Abad XVII \& XVIII: Akar Pembaruan Islam Indonesia. Jakarta: Kencana, 2005.

Bakar, M. Abu. "Al-Ittihadiyah 1/4 abad." Bachroem Azhar, et al.. Peringatan Ulang Tabun 1/4 Abad Al-Ittihadiyah. Medan: Panitia Bear Kongres ke X Al-Ittihadiyah, 1960.

C.V.O Conferentie Al-Ittihadiyah. "Azas, toejoean, oesaha, dan organisatie Al-Ittihadiyah." Conferentie Jubilieum 6 Taboen 19351941 Al-Ittihadiah. n.p.: C.V.O. Conferentie Al-Ittihadiah ke-I, 1941.

Daulay, Pangadilan, \& Hawari Arsyad Lubis, (ed.). Al Jam'iyatul Washliyah Memasuki Millenium III: Kado Ulang Tabun Al-Washliyah ke-69 Tahun 1999. Jakarta: Pengurus Besar Al-Washliyah, 1999.

Djamil, Bahrum. "Masa Depan Madrasah/Perguruan Al-Washliyah." in Nukman Sulaiman (ed.). Al Jam'iyatul Washliyah 1/4 Abad. Medan: Pengurus Besar Al Jam’iyatul Washliyah, 1955.

Djamin, Djanius. "Selayang pandang kiprah Al-Ittihadiyah." in Anzizhan and Syafaruddin (ed.). Al-Ittibadiyah Menjalin Kebersamaan Membangun Bangsa. Jakarta: Hijri Pustaka Utama, 2006.

Ecip, S. Sinansari. NU, Khittah dan Godaan Politik. Bandung: Mizan, 1994.

Yusuf, Slamet Effendy. Dinamika Kaum Santri: Menelusuri Jejak dan Pergolakan Internal NU. Jakarta: Rajawali, 1983.

Fealy, Greg \& Greg Barton. Nabdlatul Ulama Traditional Islam and Modernity in Indonesia. Australia: Monash University, 1996.

Federspiel, Howard M. Persatuan Islam Islamic Reform in Twentieth Century Indonesia. Singapore: Equinox Publishing Pte. Ltd., 2009.

Haitamy, M. Nur. "Muhammadiyah Daerah Sumatera Timur." in 30 Tahun Mubammadiyah di Daerah Sumatera Timur. Medan: Panitia Besar Peringatan, 1967.

Hasan, Chalidijah. Al Jam'iyatul Washliyab: Api dalam Sekam. Bandung: Pustaka, 1988.

Ja'far. Biografi Intelektual Ulama-ulama Al-Washliyah. Medan: Centre for Al-Washliyah Studies, 2012. 
Jasin, Hasbi (ed.). Al Jam'iyatul Washliyah: Sekilas Catatan Muktamar Penuh Kasih Sayang Menghasilkan Demokrasi yang Utuh. Jakarta: PB Al Jam'iyatul Washliyah, 1997.

Lubis, Muhammad Arsyad Thalib. Fatwa. Medan: Firma Islamiyah, 1982.

Lubis, Saiful Akhyar (ed.). Peran Moderasi Al-Washliyah: Merajut Kebersamaan Zaman Berzaman. Medan: UNIVA Press, 2009.

Majelis Pendidikan dan Kebudayaan Al Jam'iyatul Washliyah Sumatera Utara. Nama dan Alamat Sekolah/Madrasah Al Jam'iyatul Washliyah Propinsi Sumatera Utara. Medan: MPK Al-Washliyah, 1995.

Majelis Ulama Indonesia Sumatera Utara. Sejarah Ulama-ulama Terkemuka di Sumatera Utara. Medan: IAIN Sumatera Utara, 1983.

Mas'ud, Abdurrahman. Dari Haramain ke Nusantara: Jejak Intelektual Arsitek Pesantren. Jakarta: Kencana, 2006.

--------. Intelektual Pesantren: Perhelatan Agama dan Tradisi. Yogyakarta: LKiS, 2004.

Mehden, Fred vo der. Sarekat Islam. Oxford: Oxford University Press, 2011.

Moehammadijah, HB. Moehammadijah Hindia Timur 1927-1932. Jogjakarta: HB Moehammadiyah, 1933.

Mu'thi, Abdul. 30 tahun Muhammadiyah di daerah Sumatera Timur." in 30 Tabun Muhammadiyah di Daerah Sumatera Timur. Medan: Panitia Besar Peringatan, 1957.

MUI Sumatera Utara. Fatwa \& Hukum tentang Jema'ah Ahmadiyah Qadiyany. Medan: MUI Sumatera Utara, n.d.

Mulkhan, Abdul Munir. Kiai Abmad Dablan: Jejak Pembaruan Sosial dan Kemanusiaan. Jakarta: Kompas, 2010.

Nashir, Haidar. Dinamika Politik Muhammadiyah. Yogyakarta: Bigraf Publishing, 2000.

Nasution, Tanwir Ahmad. Sejarah Berdirinya Daerah Mubammadiyah Kabupaten Tapanuli Selatan. n.p: n.p., 2005.

Noer, Deliar. Gerakan Modern Islam di Indonesia 1900-1942. Jakarta: LP3ES, 1994. 
Pelly, Usman. Urbanisasi dan Adaptasi: Peranan Misi Budaya Minangkabau dan Mandailing. Jakarta: LP3ES, 1994.

Pengurus Besar Al Jam'iyatul Washliyah. Al Jam'iyatul Washliyah. Medan: Pengurus Besar Al Jam’iyatul Washliyah, 1977.

--------. Anggaran Dasar dan Anggaran Rumah Tangga Al Jam'iyatul Washliyah Periode 2003-2008. Jakarta: PB Al-Washliyah, 2003.

- Anggaran Dasar dan Anggaran Rumah Tangga Al Jam'iyatul Washliyah Periode 2010-2015. Jakarta: Pengurus Besar Al Jam'iyatul Washliyah, 2010.

--------. Laporan Umum Pimpinan Wilayah Al Jam'iyatul Washliyah Sumatera Utara: Musyawarah Wilayah X Al Jam'iyatul Washliyah Sumatera Utara. Medan: PW Al-Washliyah Sumatera Utara, 2003.

Pulungan, Abbas. Perkembangan Islam di Mandailing. Bandung: Citapustaka Media, 2008.

-. Riwayat Singkat Syekh Musthafa Husein, Syekh Abdul Halim Khatib dan Haji Abdullah Musthafa. Medan: Perdana Publishing, 2012.

---------, et. al.. Sejarah dan Dinamika Organisasi Islam di Sumatera Utara. Medan: Institut Agama Islam Negeri Sumatera Utara, 2005.

Remantan, M. Daud. "Gerakan Pembaruan Islam di Aceh (19141953)." Unpublished Dissertation, IAIN Syarif Hidayatullah, 1986.

Shihab, Alwi. Membendung Arus: Respons Gerakan Mubammadiyah terhadap Penetrasi Misi Kristen di Indonesia. Bandung: Mizan, 1998.

Siddik, Dja'far, Rosnita \& Ja'far. Lembaga-lembaga Pendidikan AlWashliyah: Tipologi, Eksistensi dan Problematika. Medan: Lemlit IAIN Sumatera Utara, 2012.

Siddik, Dja'far. “Konsep Pendidikan Islam Muhammadiyah: sistematisasi dan interpretasi berdasarkan perspektif ilmu pendidikan." Unpublished Dissertation, IAIN Sunan Kalijaga, 1997.

. Pendidikan Mubammadiyah Perspektif Ilmu Pendidikan. Bandung: Citapustaka Media, 2007.

Sinar, Tengku Luckman. Sejarah Medan Tempo Doeloe. Medan: Perwira, 2007. 
Steenbrink, Karel A. Pesantren, Madrasah, Sekolab: Pendidikan Islam dalam Kurun Modern. Jakarta: LP3ES, 1986.

Sulaiman, Nukman (ed.). Al Jam'iyatul Washliyah 1/4 Abad. Medan: Pengurus Besar Al Jam’iyatul Washliyah, 1955.

Syahputra, Akmaluddin (ed.). Sejarah Ulama Langkat dan Tokoh Pendidik. Bandung: Citapustaka Media, 2012.

Syamsuddin, Udin. Chutbah Pengurus Besar Memperingati Ulang Tahun alDJam'iyatul Washlijah Seperempat Abad (30 November 1930-30 November 1955). Medan: PB al-Jam'iyatul Washliyah, 1955.

Taib, Muhammad Hasballah. Universitas Al-Washliyah Medan: Lembaga Pengkaderan Ulama di Sumatera Utara. Medan: UNIVA, 1993.

Tanjung, Muaz. "Pendidikan Islam di Medan Pada Awal Abad ke-20: Studi Historis tentang Maktab Islamiyah Tapanuli (1918-1942)." Unpublished MA Tesis: PPS IAIN-SU, 2004.

-------. Maktab Islamiyah Tapanuli 1918-1942: Menelusuri Sejarah Pendidikan Islam Awal Abad ke-20 di Medan. Medan: IAIN Press, 2012.

Wahid, Ramli Abdul. “Al-Jam’iyatul Washliyah: studi tentang madzhab akidah dan fikih." in Saiful Akhyar Lubis (ed.). Peran Moderasi AlWashliyah: Merajut Kebersamaan Zaman Berzaman. Medan: UNIVA Press, 2009.

Zulkarnain, Iskandar. Gerakan Abmadiyah di Indonesia. Yogyakarta: LKiS, 2005. 
Al Rasyidin

88 JOURNAL OF INDONESIAN ISLAM

VOLUME 1O, NUMBER O 1, JUNE 2016 